\title{
A survey on smart shoe insole systems
}

\author{
Salma Saidani ${ }^{1}$, Rim Haddad ${ }^{1}$, Neila Mezghani ${ }^{2}$,Ridha Bouallegue ${ }^{1}$ \\ ${ }^{1}$ Innov'Com laboratory, High School of communication of Tunis University of Carthage, Tunis, Tunisia \\ Email: salma.saidani@supcom.tn,rim.haddad@supcom.tn,ridha.bouallegue@supcom.tn \\ ${ }^{2}$ Laboratory of Imaging and Orthopedic Research, TELUQ University, Montreal, Qc, Canada \\ Email: neila.mezghani@teluq.ca
}

\begin{abstract}
Nowadays, the foot pressure analyze using a wearable sensing systems becomes innovative in clinical and research fields to enable real time care of patients and to accelerate the detection of diseases. The plantar pressure is measured using a smart shoe insole system with multi-sensors placed in different anatomical zones of the foot, the best position and number of sensors depends on the type of analyze.

The aim of this systematic review was to assess the measurement of plantar pressure with instrumented smart shoe insole. We studied the main characteristics of the shoe insole systems, and their ability to identify diseases and for efficient real time care of patients. The shoe insole systems are classified according to the number and types of sensors. This paper can be a valuable source of recent references for future research in the field of smart insole systems.
\end{abstract}

keywords -Foot, Plantar pressure, Multi-sensors, Shoe insole, Diseases, smart shoe

\section{INTRODUCTION}

Wearable shoe insole sensing systems are based on mhealth technology and combination of communications, sensing and human mobile interaction technologies targeted at treatment and monitoring patients. The aim of the smart insole system is to provide a remote surveillance for illness patient and enhance athletes' performances, through helping medical professionals in diagnosis and analysis.

While our foot, support all the weight of our body and have a complex structure, a bad foot position can often cause pain in the legs, knees, hips. In some cases, a walk analysis may be useful. Indeed, it is not always obvious to precisely locate the problem while standing. But once in mobility, it can increase sharply when walking or running [1]. This analysis consists of walking, standing and running of the subject using a shoe insole equipped with pressure sensors placed in different anatomical zones of the foot as shown in Figure 1. With the assistance of wireless health sensor networks, doctors will no longer need to rely solely on the information gathered through patient interviews and onsite observations, but now have the ability to gather data from the normal day to day routine of the patient, further assisting ailment and disease diagnosis [2].

According to World Health Organization (WHO), 422 Million adults have diabetes and 1.6 million deaths are directly attributed to diabetes each year.A big risk that diabetes could become the 7th leading cause of death in the world by 2030[3].

Diabetic foot disorder is classified as a medical emergency as it can become sufficiently severe and it requires amputation in some cases. Diabetic has also financially constraints according to the cost of the NHS 10\% of its annual budget which is expected to rise to $17 \%$ by 2035 in direct costs $[4,5]$.

Ulceration of the diabetic foot is currently difficult to detect in a timely manner causing patient suffering and expensive cost. Current best practice is for daily monitoring by those living with diabetics coupled to schedule care provider [6]. Although the use of the shoe insole by the subject can be useful in the detection or prediction of ulceration.

In addition, the Cardiovascular diseases (CVDs) according to WHO take the lives of 17.7 million people every year, $31 \%$ of all global deaths. Triggering these diseases - which manifest primarily as heart attacks and strokes - are tobacco use, unhealthy diet, physical inactivity and the harmful use of alcohol. These in turn show up in people as raised blood pressure, elevated blood glucose and overweight and obesity, risks detrimental to good heart health [7]. Furthermore, physical activity contributes to weight loss and improved blood pressure and lipid profile [8-9]. Walking has the primary role in both primary and secondary prevention of CVD. Thirty minutes of walking per day reduces the risk of coronary heart disease by $19 \%$ [10, 11]. An exercising human should undertake 3000 steps during $30 \mathrm{~min}$ to feel warm and to sweat lightly [12,13].

In fact, obesity is associated with diabetes and cardiovascular disease, however obesity is also associated with musculoskeletal disorders affecting the lower limb, such as knee and hip osteoarthritis.[14]

In 2016, more than 1.9 billion adults aged 18 years and older were overweight [15]. By 2030, the number of overweight people is expected to reach 3.3 billion [16].

In this paper we present a literature overview on smart shoe insole systems instrumented by multi-sensor. In fact, we classify the shoe insole systems according to the type of sensors, the number of used sensors, the sensors location and the clinical use of the monitoring system. In this paper, we present the design of wearable insole technology, called "Smart Insole", and evaluate its performance in the prevention and monitoring of diseases such as diabetes, obesity and cardiovascular. Using the intelligent shoe insole, all the human activity can be supervised without disturbing the quality lifestyle of the subject.

The remainder of the paper is structured as follows: Section II describes the architecture of the smart insole system. In Section III we present a comparative study of different smart shoe insole systems.In section IV we analyze the plantar pressure using the smart insole systems . In section $\mathrm{V}$ we discuss the clinical utility of the smart insole system with different types and numbers of sensors. In Section VI, we conclude and outline the future work. 


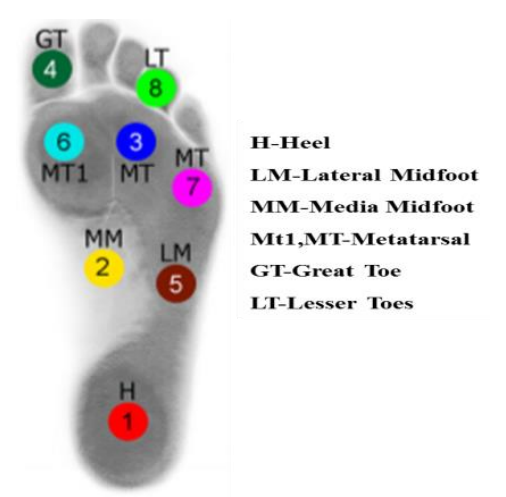

Figure 1.Sensors distribution inside the smart shoe insole [17]

\section{SMART SHOE INSOLE SYSTEM}

\section{A. System overview}

The Smart Insole system is a wearable and affordable technology, which addresses the current issues in gait analysis. The smart insole system integrates motion sensing components within shoe insoles. With the intelligent analysis algorithm, all important human gait features can be retrieved from the sensor data. Therefore, the Smart Insole system can monitor all types of activities in free-living without disturbing the normal life of the subject. [18]

\section{B. Hardware architecture}

The Smart Insole system comprises a low-cost sensory insole and application software on both smartphone and computer for data storage and visualization. The insole consists of an array of sensors, an ultra-low power micro control unit (MCU) and Bluetooth low energy (BLE) wireless transmission module, a channel multiplexer (MUX), a battery, and a micro-Universal Serial Bus (USB) connector module. The application software provides visualization and a real-time guided feedback to the user. The data stored in Secure Digital (SD) card will be used to study lifestyle and health behaviors that facilitate new understanding and effective intervention options to promote individual independence. Specifically, Smart Insole can measure step counts, step pace, swing time, and center of pressure (COP) shifting velocity, which can further infer the walking balance status and potential fall risk in real life. [19]

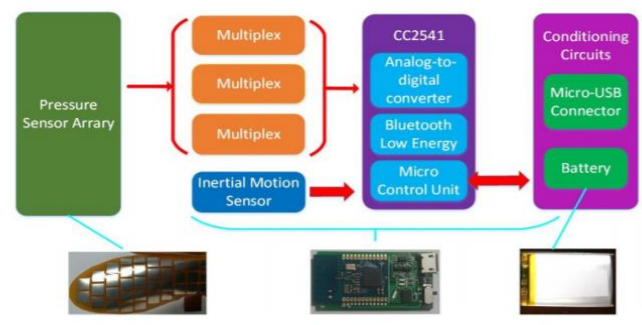

Figure 2.The design of Smart insole [20].
According to Wenyao et al, [18], there are three important subsystems as shown in Figure 3 . The first subsystem is low cost sensors for gait characterization, including 48 pressure sensors, 3-axis accelerometer, 3-axis gyroscope and 3-axis compass. The pressure sensor array is used to obtain the high-solution pressure map under foot. It is based on advanced fabric sensor techniques [21] and can be efficiently integrated in the Smart Insole system. The accelerometer and gyroscope are inertial sensors, and can measure the movement information of the subject. The compass is used as the baseline when the inertial sensors (accelerometer and gyroscope) are calibrated. The second subsystem is the signal acquisition and transmission module. The sample rate can be adapted to the specific applications, up to 100 samples per second $(\mathrm{Hz})$. After that, the quantified sensor data is streamed in real-time to a data aggregator. With one 1200-mAh Li-battery, the system can continuously work for over 24 hours. Therefore, the Smart Insole system can be used daily without interruption and without charging the battery. The third subsystem is the sensor aggregation and processing module developed on a smart phone to store and analyze the raw data it receives .[18]

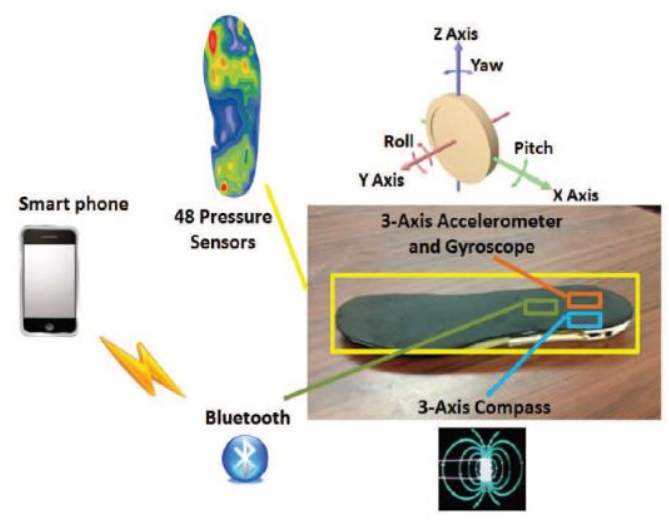

Figure 3: The system architecture of Smart Insole System [18].

\section{COMPARATIVE STUDY OF SMART SHOE INSOLE SYSTEMS}

The analysis of plantar pressure during the daily life of the subjects based on wearing mobile systems, is able to measure the pressure during the gait with high precision, repeatable data throughout the subject's gait cycle.

The system design must be thin and flexible so that it will not be perceived by the subject. The sensor must be durable and capable of withstanding repetitive gait cycles, yet small and thin in order to fit in the insole. It should have high sensitivity, yet be able to withstand large overloads. It should have a short response time and low power consumption [20].

Many devices are available, and differ from each other by the size, sensors number, sensors type and therefore their response to loading and their accuracy for data analysis and treatment. The strengths and weaknesses of each system is measured in terms of validity and repeatability influence of 
each device for specific tasks in both clinical and research settings [21].

There are many smart devices used for measuring the plantar pressure of the feet characterized by sensor types, sensor number, battery battery lifetime and communications mode summarized in table I.

TABLE I. COMPARATIVE STUDY OF SMART SHOE INSOLE SYSTEMS

\begin{tabular}{|c|c|c|c|c|}
\hline Shoe insole & Sensor type & $\begin{array}{l}\text { Sensor } \\
\text { Number }\end{array}$ & $\begin{array}{l}\text { Battery } \\
\text { lifetime }\end{array}$ & $\begin{array}{c}\text { Communications } \\
\text { mode }\end{array}$ \\
\hline F-Scan[22] & Resistive & 960 & 2 hours & USB \\
\hline Dynafoot2[23] & $\begin{array}{c}\text { Resistive } \\
\text { Accelerometer }\end{array}$ & 58 & $\begin{array}{c}3.5 \\
\text { hours }\end{array}$ & Bluetooth \\
\hline Wiisel[24] & $\begin{array}{l}\text { Resistive } \\
\text { Accelerometer } \\
\text { Gyroscope }\end{array}$ & 14 & N/A & Bluetooth \\
\hline Moticon[25] & $\begin{array}{c}\text { Capacitive } \\
\text { 3D } \\
\text { Accelerometer }\end{array}$ & 13 & N/A & Wireless \\
\hline $\begin{array}{c}\text { Pedar-X } \\
\text { Insole[26] }\end{array}$ & Piezo electric & 99 & $\begin{array}{c}4.5 \\
\text { hours }\end{array}$ & $\begin{array}{l}\text { Bluetooth } \\
\text { USB } \\
\text { Optical fiber }\end{array}$ \\
\hline $\begin{array}{c}\text { Orpyx } \\
\operatorname{LogR}[27]\end{array}$ & N/A & 8 & $\begin{array}{l}8-12 \\
\text { hours }\end{array}$ & Bluetooth \\
\hline $\begin{array}{l}\text { Footwork } \\
\text { Insole[28] }\end{array}$ & Capacitive & 80 & 3 hours & $\begin{array}{l}\text { Bluetooth } \\
\text { USB }\end{array}$ \\
\hline $\begin{array}{l}\text { Medilogic } \\
\text { Insole[29] }\end{array}$ & N/A & 240 & $\begin{array}{c}16 \\
\text { hours }\end{array}$ & Wireless \\
\hline Biofoot[30] & Piezo electric & 64 & N/A & $\begin{array}{l}\text { Wi-fi } \\
\text { USB }\end{array}$ \\
\hline Paro-tech[31] & $\begin{array}{l}\text { Piezo Resistive } \\
\text { Hydro_cell }\end{array}$ & 24 to 36 & N/A & Memory Card \\
\hline $\begin{array}{l}\text { Sensor Medica } \\
\text { Flexinfit[32] }\end{array}$ & Resistive & 214 & 4 hours & Bluetooth \\
\hline $\begin{array}{c}\text { Sennopro Insole } \\
\text { X[33] }\end{array}$ & $\begin{array}{c}\text { Textile Sensors } \\
\text { Accelerometer } \\
\text { Gyroscope }\end{array}$ & 48 & $\begin{array}{c}48 \\
\text { hours }\end{array}$ & Bluetooth \\
\hline Digitsole[34] & N/A & N/A & $\begin{array}{l}7 / 8 \\
\text { hours }\end{array}$ & $\begin{array}{l}\text { Bluetooth } \\
\text { USB }\end{array}$ \\
\hline $\begin{array}{l}\text { Arion smart } \\
\text { Insoles [35] }\end{array}$ & $\begin{array}{l}\text { Accelerometer, } \\
\text { Gyroscope and } \\
\text { GPS. }\end{array}$ & 8 & 7 hours & Bluetooth \\
\hline
\end{tabular}

\section{ANALYSIS OF PLANTAR PRESSURE}

Plantar pressures can be modified by neurological, orthopedic, mal-formative or metabolic pathologies. The quantified analysis of the plantar pressure distribution is one of the possible instrumental techniques for objectifying these modifications. It can be performed by multi-sensor onboard soles, allowing the dynamic measurement of plantar pressures or the measurement of the trajectory of the center of pressure during walking. When a surgical indication is asked, the main objective is that of a restoration or improvement of the walk by a better distribution of the plantar supports. Onboard baro-podometric analysis using multi-sensor soles allows objective evaluation of results after surgery [36].

The key factors affecting foot pressure and foot structure during dynamic activities: walking and running, gender (female, male), the race,age,size ,the weight body movement and walking [37].

\section{DISCUSSION}

The validity of smart insole measurements for monitoring patients have been assessed a tremendous number of research studies. The smart insole system characteristics are summarized in the Table II and Table III in order to analyze and compare, respectively, their architecture and their utility.All the systems are classified according to the sensors type; pressure sensor, resistive sensor, PVDF sensors, Accelerometer, Rotation, Humidity, Temperature, GSR(Galvanic Skin Response), Bioimpedance, Force, Temperature skin. The aim of such researches is to find the different physiological information obtained by the most smart insole devices to control and predict diseases. The efficiency of these smart devices is related to the box of data collector, send data through Bluetooth to the mobile station or to the computer, then all the information will be analyzed by the clinician, the doctor and even by the patient itself.

Table II, classifies insoles according to the number of sensors, type, the information provided by sensors can be used to analyze the patient's health, sensor location of the sensor and its thickness should not affect the comfort of the patient in walking. Battery features is the aim of our future research to continue the control of human activity for a significant number of hours.

The table III, presents a comparison between the systems based on the error rate, the clinical utility to facilitate the diagnostic of the diseases while each patient in the test is characterized by a set of characteristics (Age,Gender, Weight, Height,BMI,...).

\section{CONCLUSION}

In the context of medical supervision for patients. One of the approaches based on m-health technology, is using a smart insole to enable the doctors to follow up and analyze the patient's physiological data history during his absence in the medical center. The data is sampled and stored in 
dedicated devices, avoiding patients' regular travel costs or permanent presence in medical centers. Furthermore, the mobile patient must carry a device, for the backup of the data produced by the smart insole sensors. Once the memory of the device is returned by the doctor, the latter retrieves the physiological history of the patient and performs its analysis and diagnosis.

In the future work, we will propose a design of a smart insole system with allows real-time monitoring of patients physiological conditions without disturbing the quality of lifestyle, comforting, easy to use, cheap, and the data storage as the sensing must be unobtrusive. Our challenges are to make the system functional for twenty four hours to control and monitor different human activities, through real-time processing and data transmission, healthcare suppliers will be able to monitor the subject's motions during daily activities and also to detect unpredictable events that may occur, like a fall for elderly subject.

\section{REFERENCES}

[1]ArenaOrthopédie.Available:.http://www.orthopediste-nice.com/analysede-la marche.

[2] James B. Wendt and Miodrag Potkonjak. Medical Diagnostic-Based

Sensor Selection.

[3] World Health Organization Available:http://www.who.int/diabetes/en/.

[4] Hex, N.; Bartlett, C.; Wright, D.; Taylor, M.; Varley, D. Estimating the current and future costs of Type 1 and Type 2 diabetes in the UK, including direct health costs and indirect societal and productivity costs. Diabet. Med. 2012, 29, 855-862.

[5] Lavery, L.A.; Higgins, K.R.; Lanctot, D.R.; Constantinides, G.P.; Zamorano, R.G.; Armstrong, D.G.;Athanasiou, K.A.; Agrawal, C.M. Home monitoring of foot skin temperatures to prevent ulceration. Diabet. Care 2004, 27, 2642-2647.

[6] James Coates ,Andrew Chipperfield, and Geraldine Clough. Wearable Multimodal Skin Sensing for the Diabetic Foot.2016.

[7] Cardiovascular disease .Available:http://www.who.int/cardiovascular_diseases/world-heartday-2017/en/.

[8] Centers for Disease Control and Prevention 2016 Physical

Activity www.cdc.gov/healthyplaces/healthtopics/physactivity.htm.

[9] Kelley G A, Kelley K S and Tran Z V 2003 Walking and non-

HDL-C in adults: a meta-analysis of randomized controlled $\mathrm{n}$ trials Prev Cardiol. 8 102-7.

[10] U.S. Department of Health and Human Services 2008 Physical Activity Guidelines for Americans ODPHP Publication No.U0036 www.health.gov/paguidelines/pdf/paguide.pdf.

[11] Zheng H, Orsini N, Amin J, Wolk A, Nguyen V T and Ehrlich F 2009 Quantifying the dose-response of walking in reducing coronary heart disease risk: meta-analysis Eur. J. Epidemiol. 24 181-92.

[12] Murtagh E M, Murphy M H and Boone-Heinonen J 2010 Walkingthe first steps in cardiovascular disease prevention Curr. Opin. Cardiol. 25 490-6.

[13] Marshall S, Levy S, Tudor-Locke C, Kolkhorst F W,

Wooten K M, Ji M, Macera C A and Ainsworth B E 2009 Translating physical activity recommendations into a pedometer-based step goal 3000 steps in 30 minutes Am. J.Prev. Med. 36 410-5.

[14] Paul A. Butterworth, Donna M. Urquhart, Karl B. Landorf, Anita E. Wluka d, Flavia M. Cicuttini d, Hylton B. Menz. Foot posture, range of motion and plantar pressure characteristics in obese and non-obese individuals.2014.

[15] Obesite santé .Available:http://www.obesitesante.com/comprendre_1_ obesite/obesite_et_surpoids/definitions.shtml
[16] World Health Organization.Available:http://www.who.int/newsroom/fact-sheets/detail/obesity-and overweight.

[17] E Klimiec, B Jasiewicz, J Piekarski, K Zaraska, P Guzdek

and G Kołaszczyński. Measuring of foot plantar pressure possible applications in quantitative analysis of human body mobility.2017.

[18] Wenyao Xu et al, Smart insole: A wearable system for gait analysis. 2012.

[19] Feng Lin et al,. Smart Insole: a Wearable Sensor Device for Unobtrusive Gait Monitoring in Daily Life.2016.

[20]Feng Lin et al,.A Comparative Study of Smart Insole on Real-world Step Count.2015.

[21] W. Xu, Z. Li, M.-C. Huang, N. Amini, and M. Sarrafzadeh, "ecushion: An etextile device for sitting posture monitoring," in BSN, pp. 194199, 2011.

[22] Tekscan, South Boston, MA, USA, "F-Scan in-shoe analysis system." Available: https://www.tekscan.com/products-solutions/systems/t-scan.

[23] Techno Concepts, Pitaugier, France, 2015. "Dynafoot 2," Techno Concepts.

[24] WIISEL, "Wireless insole for independent and safe elderly living,"2013.Available: http://www.wiisel.eu/?q=content/documents.

[25] Moticon GmbH, Munich, Germany, "Moticon science," Product Home,2015. Available: http://www.moticon.de/products/producthome.

[26] Novel, "Pedar system - the quality in-shoe dynamic pressure measuring system." 2008. Available: http://novel.de/novelcontent/pedar.

[27] ORPYX Medical Technologies, Calgary, AB, Canada, "LogR-Orpyx Medical Technologies-Real-time measurement of plantar pressure for analysis by researchers." 2016.Available: https://orpyx.com/pages/logr. [28] amcube, Berkshire, U.K. "In-shoe pressure measurement | mobile foot pressure measurement," In-Shoe Pressure Measurement Mobile \& Practical.2015.Available: http://www.amcube.co.uk/products/inshoepressure-measurement/.

[29] medilogic, Sch"onefeld,Germany, "Medilogic insole science." 2016.

Available: http://www.medilogic.com/en/products-human/foot pressure measurement/medilogic-insole/.

[30] "Sistema Biofoot/IBV," Instituto de Biomec'anica de Valencia, Valencia,Spain, 2012.

[31] Paromed, "paroTec: The high-precision foot pressure measurement system,"Paromed, Neubeuern, Germany, Products.. Available:

http://www.paromed.biz/paroTec-3-2.html

[32] Sensor Medica, Guidonia, Italy, "Sensor Medica cataloge," Design \& Development by Sensor Medica, 2017. Available: http://www.

sensormedica.com/site/SM catalogue 2017.pdf.

[33] Sennotech Co. Ltd., Shenzhen, China. "Sennotech sensing innovative,’Insole Smart \& Natural. 2016. Available: http://www.

sennotech.com/EN/product/insole.php.

[34] Digitsole: The first interactive insole to heat your feet.2018.Available: https://www.kickstarter.com/projects/1308642275/digitsole-the-firstinteractive-insole-to-heat-you.

[35] ARION Footpod GPS,Sensor-packed footpod with GPS.2018.Available: https://www.arion.run/product/arion-footpodgps/.

[36]Abdul Hadi Abdul Razak, Aladin Zayegh, Rezaul K. Begg, and Yufridin Wahab 2012 foot plantar pressure measurement system: a review.

[37] M Kramer, MA, BA (HMS) Hons (Biokinetics), PhD; R du Randt, PhD; DVenter, PhD.2015 Dynamic plantar pressure profiles of South African university students. 
TABLE II. SUMMARY OF INCLUDED STUDIES

\begin{tabular}{|c|c|c|c|c|c|c|c|}
\hline Author/s & Sensor Type & $\begin{array}{l}\text { Number } \\
\text { of sensor }\end{array}$ & $\begin{array}{c}\text { Information } \\
\text { provided by sensors }\end{array}$ & Sensors Location & $\begin{array}{l}\text { Instrumented } \\
\text { shoe insole } \\
\text { characteristics }\end{array}$ & $\begin{array}{l}\text { Data transfer } \\
\text { technology }\end{array}$ & Battery features \\
\hline $\begin{array}{l}\text { Ewa Klimiec et } \\
\text { al., 2014[18] }\end{array}$ & PVDF sensors & 8 & $\begin{array}{l}\text { The plantar pressure } \\
\text { usual activities such } \\
\text { as walking, running } \\
\text { or jumping in } \\
\text { natural environment. }\end{array}$ & Under the foot. & $\begin{array}{l}\text { Thickness of } \\
\text { sole }, 4 \mathrm{~mm} . \\
\text { surface area of } \\
\text { each } \\
\text { sensor, } 1.5 \mathrm{~cm}^{2} \text {. }\end{array}$ & $\begin{array}{l}\text { Bluetooth } \\
2.4 \mathrm{GHz} \text {. }\end{array}$ & $\begin{array}{l}\text { Li-ion cell with } \\
\text { the capacity of } \\
720 \mathrm{mAh} .\end{array}$ \\
\hline $\begin{array}{c}\text { James B. Wendt } \\
\text { and Miodrag } \\
\text { Potkonjak., } \\
\text { 2010[19] }\end{array}$ & Pressure sensors. & $\begin{array}{l}\text { Reducing } \\
\text { from } 99 \text { to } \\
12 .\end{array}$ & $\begin{array}{l}\text { Retain only the } \\
\text { necessary diagnostic } \\
\text { metric predictability. }\end{array}$ & Under the foot. & N/A. & $\begin{array}{c}\text { Data is collected } \\
\text { at } 60 \mathrm{~Hz} .\end{array}$ & N/A. \\
\hline $\begin{array}{l}\text { E Klimiec et } \\
\text { al.,2017 [7] }\end{array}$ & $\begin{array}{l}\text { Piezoelectric } \\
\text { sensors made of } \\
\text { polarized PVDF } \\
\text { foil. }\end{array}$ & 8 & $\begin{array}{l}\text { Gait rhythm, foot to } \\
\text { ground } \\
\text { contact time, } \\
\text { maximum minimum } \\
\text { and average electric } \\
\text { signal. }\end{array}$ & $\begin{array}{c}\text { Sensor } 1 \text { on } \\
\text { hell(H),Sensor } 2 \\
\text { on midfoot(MM), } \\
\text { Sensor } 3 \text { on } \\
\text { metatarsal(MT),Se } \\
\text { nsor } 4 \text { on great } \\
\text { toe(GT),Sensor } 5 \\
\text { on lateral } \\
\text { midfoot(LM),Sens } \\
\text { or } 6 \\
\text { onmetatarsal(MT1) } \\
\text {,Sensor } 7 \text { on } \\
\text { metatarsal(MT),Se } \\
\text { nsor } 8 \text { on } \\
\text { lesser toes(LT). }\end{array}$ & $\begin{array}{l}\text { The insole is less } \\
\text { than } 4 \mathrm{~mm} \text { thick. } \\
\text { Surface area of } \\
\text { each sensor } \\
1.5 \mathrm{~cm}^{2} . \\
\text { Shoe insole, } \\
\text { placed inside a } \\
\text { sports shoe. }\end{array}$ & $\begin{array}{c}\text { Data are } \\
\text { transmitted } \\
\text { in packet form, } \\
\text { with address and } \\
\text { error detection } \\
\text { codes. }\end{array}$ & $\begin{array}{l}\text { Rechargeable } \\
\text { Li-ion LIR2450 } \\
\text { cell with the } \\
\text { capacity of } 120 \\
\text { mAh. } \\
\text { up to } 2 \text { h } \\
\text { continuous } \\
\text { operation. }\end{array}$ \\
\hline $\begin{array}{c}\text { James Coates et } \\
\text { all.,2016[6] }\end{array}$ & $\begin{array}{c}\text { Multi- } \\
\text { sensor(Accelero } \\
\text { meter, Rotation, } \\
\text { Humidity, } \\
\text { Temperature, } \\
\text { GSR, } \\
\text { Bioimpedance, } \\
\text { Force, } \\
\text { Temperature } \\
\text { skin). }\end{array}$ & 42 & $\begin{array}{l}\text { Acceleration, } \\
\text { rotation, galvanic } \\
\text { skin response, } \\
\text { environmental } \\
\text { temperature, } \\
\text { humidity, force, skin } \\
\text { temperature and } \\
\text { bioimpedance signals } \\
\text { in real } \\
\text { time. }\end{array}$ & $\begin{array}{l}\text { Force and } \\
\text { temperature } \\
\text { sensors are } \\
\text { positioned over the } \\
\text { calcaneus (heal), } \\
\text { great toe, 1st } \\
\text { metatarsal (joint at } \\
\text { the base of the } \\
\text { great toe), } 5 \text { th } \\
\text { metatarsal (joint at } \\
\text { the base of the } \\
\text { small toe). GSR } \\
\text { can be seen below } \\
\text { the } 5 \text { th metatarsal } \\
\text { force sensor with } \\
\text { bioimpedance } \\
\text { placed mid foot. }\end{array}$ & N/A. & $\begin{array}{l}\text { Bluetooth and } \\
\text { Wi-Fi data } \\
\text { acquisition } \\
\text { Device. } \\
\text { utilised a } \\
\text { sampling } \\
\text { frequency of } 20 \\
\text { Hz to enable the } \\
\text { gathering of } \\
\text { larger data. Real } \\
\text { time. }\end{array}$ & $\begin{array}{c}\text { Battery } 3.7 \mathrm{~V} \\
900 \mathrm{mAh} \sim 2.5 \\
\mathrm{~h} . \\
\text { Batteries } \\
\text { being replaced } \\
\text { every two hours. }\end{array}$ \\
\hline $\begin{array}{l}\text { E.S. da Rocha et } \\
\text { al.,2014[20] }\end{array}$ & Pressure sensors. & N/A. & $\begin{array}{l}\text { Plantar pressure in } \\
\text { the foot ,the forefoot, } \\
\text { midfoot and rearfoot. }\end{array}$ & $\begin{array}{l}\text { Distributed in the } \\
\text { forefoot ,midfoot } \\
\text { and rearfoot }\end{array}$ & N/A. & $\begin{array}{l}\text { Plantar pressure } \\
\text { for obese and } \\
\text { non-obese } \\
\text { participants was } \\
\text { recorded } \\
\text { at sampling rate } \\
\text { of } 100 \mathrm{~Hz} \text {. }\end{array}$ & N/A. \\
\hline $\begin{array}{l}\text { Lin Shu } \\
\text { al.,2010[21] }\end{array}$ & $\begin{array}{l}\text { Resistive } \\
\text { sensors. }\end{array}$ & 6. & $\begin{array}{l}\text { Mean pressure, peak } \\
\text { pressure, center of } \\
\text { pressure (COP), and } \\
\text { shift speed of COP. }\end{array}$ & $\begin{array}{c}\text { At heel and } \\
\text { metatarsal areas }\end{array}$ & N/A. & $\begin{array}{l}\text { Real Time. } \\
\text { Bleutooth. }\end{array}$ & $\begin{array}{l}3.7 \text { V Li-ion } \\
\text { removable and } \\
\text { rechargeable } \\
\text { battery. }\end{array}$ \\
\hline
\end{tabular}


TABle III.Plantar PRESSURE MEASUREMENT TESTS

\begin{tabular}{|c|c|c|c|c|}
\hline Author/s & $\begin{array}{c}\text { Participant Number and } \\
\text { characteristics }\end{array}$ & Clinical utility & Tests & Error rates \\
\hline Ewa et al.2014 & N/A. & $\begin{array}{l}\text { Diabetes, flat feet, } \\
\text { rehabilitation after injures, } \\
\text { posture diseases and } \\
\text { in training of the athletes. }\end{array}$ & $\begin{array}{c}\text { Pressure measurement } \\
\text { during usual walking (speed ca. } 4 \mathrm{~km} / \mathrm{h} \text { ) on } \\
\text { three time: } \\
0.15,0.32 \text { and } 0.5 \mathrm{~s} \text { after beginning of the } \\
\text { step. }\end{array}$ & N/A. \\
\hline $\begin{array}{c}\text { James B. Wendt and } \\
\text { Miodrag Potkonjak., } \\
2010\end{array}$ & N/A. & $\begin{array}{l}\text { Helping medical professionals } \\
\text { and } \\
\text { specialists diagnose patient } \\
\text { illness and ailments through } \\
\text { remote surveillance. }\end{array}$ & $\begin{array}{l}\text { Tracking of the average } \\
\text { maximum step amplitude, the change in } \\
\text { step stride, and the } \\
\text { left-right pressure ratio }\end{array}$ & Less than $5 \%$. \\
\hline $\begin{array}{c}\text { E Klimiec et al.,2017 } \\
{[3]}\end{array}$ & $\begin{array}{c}3 \text { Participants with } \\
\text { BMI }(22.0,30.7,22.4) \text {. }\end{array}$ & $\begin{array}{l}\text { Can be used for stress test of } \\
\text { people with CVD } \\
\text { during preventional and health } \\
\text { recovery exercises. }\end{array}$ & $\begin{array}{l}\text { Two tests evaluation :- the foot pressure } \\
\text { under heel,the gait. } \\
\text { Two tracking scenario for all sensors } \\
\text { during normal and slow walk: -Averaged } \\
\text { traces and } \\
\text { Mean energy. }\end{array}$ & N/A. \\
\hline $\begin{array}{l}\text { James Coates et } \\
\text { all.,2016[6] }\end{array}$ & $\begin{array}{l}16 \text { Healthy individuals }(15 \text { Male, } 1 \\
\text { Female).The caracterisctics of } \\
\text { subjects : } \\
\text { Age,Gender,Weight,Height,BMI, } \\
\text { blood pressure. }\end{array}$ & $\begin{array}{l}\text { The detection and prediction } \\
\text { of ulceration for the diabetic } \\
\text { foot. }\end{array}$ & $\begin{array}{l}3 \text { tests evaluation :- In Shoe Testing with } 9 \\
\text { scenario (free standing,then sitting in a } \\
\text { rigid office chair then walking at } 2.0 \mathrm{~km} / \mathrm{h} \\
\text { on the treadmill,and walking at } 4.5 \mathrm{~km} / \mathrm{h} \\
\text { on the treadmill,back to free standing, then } \\
\text { walking twice at a self-selected pace, then } \\
\text { free standing again ,and finally sitting in a } \\
\text { rigid office chair). } \\
\text { - Bioimpedance Testing with } 2 \text { scenario } \\
\text { (First, each volunteer placed a foot on the } \\
\text { sensor } 10 \mathrm{~s} \text { into the test while seated, then } \\
\text { standing at } 100 \mathrm{~s} \text { with weight evenly } \\
\text { distributed between both feet, the test } \\
\text { concluding at } 200 \mathrm{~s} \text {,Second the volunteer } \\
\text { was seated } \\
\text { and a pressure cuff placed around the } \\
\text { upper thigh of the test leg, data recording } \\
\text { was started, with the foot placed on the } \\
\text { sensor after } 10 \mathrm{~s} \text { ). } \\
\text { - The occluded blood flow test was } \\
\text { undertaken with a } 1 \text { min. }\end{array}$ & $\begin{array}{c} \pm 1.0 \% \text { for } \\
\text { Humidity. } \\
\pm 0.5^{\circ} \mathrm{C} \text { for } \\
\text { Temperature. } \\
\pm 1.0 \% \text {, or } \\
\pm 2.0 \% \text { error was } \\
\text { accepted for } \\
\text { GSR. } \\
\pm 0.05 \% \mathrm{~g} \text { for - } \\
\text { acceleration. } \\
\pm 2.0 \% \text { for the } \\
\text { rotation. }\end{array}$ \\
\hline $\begin{array}{l}\text { E.S. da Rocha et } \\
\text { al.,2014 }\end{array}$ & $\begin{array}{c}40 \text { participants : } 20 \text { obese children } \\
(13 \text { female, } 7 \mathrm{male}) \text { body mass } 41.07 \\
(7.41) \mathrm{kg} \text {; height } 1.41(0.09) \mathrm{m} \text {; BMI } \\
20.67(1.78) \mathrm{kg} / \mathrm{m} 2] \text { and } 20 \text { non- } \\
\text { obese children }(10 \text { female, } 10 \text { male }) \\
\text { body mass } 29.85(7.90) \mathrm{kg} \text {; height } \\
1.34(0.11) \mathrm{m} ; \mathrm{BMI} 16.27(1.61) \\
\mathrm{kg} / \mathrm{m} 2] .\end{array}$ & $\begin{array}{l}\text { Monitoring the sensitivity and } \\
\text { plantar pressure for obese } \\
\text { children to avoid the risk of } \\
\text { foot injuries. }\end{array}$ & $\begin{array}{l}\text { The children were tested while resting in a } \\
\text { supine position in a quiet, distraction-free } \\
\text { environment. They were blindfolded in } \\
\text { order to avoid participants to observe their } \\
\text { feet or probes during testing. }\end{array}$ & N/A. \\
\hline Lin Shu al.,2010[8] & $\begin{array}{c}18 \text { participants male characterized } \\
\text { by: } \\
\text { Height, Foot size,estimated } \\
\text { weight,and } \% \text { of the difference. }\end{array}$ & $\begin{array}{l}\text { Balanced walking statut for } \\
\text { elderly. } \\
\text { Compared the shift speed of } \\
\text { COP to the threshold value } \\
\text { serve to diagnostic the } \\
\text { musculoskeletal or } \\
\text { neurological diseases. }\end{array}$ & $\begin{array}{l}\text { Test1 for the } 8 \text { Subjects :Standing,Standing } \\
\text { on one leg,Heel strike,Push off. Each } \\
\text { subject should keep stable } 10 \mathrm{~s} \text { at each } \\
\text { action and tested for twice. } \\
\text { Test } 2 \text { for the } 10 \text { Subjets : Stand on one leg } \\
\text { over the single insole and } \\
\text { keep stable for about } 10 \mathrm{~s} \text {. }\end{array}$ & N/A. \\
\hline
\end{tabular}

